\title{
The politics of memory in Samarkand in post-Soviet period
}

\author{
Azim Malikov \\ Azim Malikov is a Senior research fellow affiliated to the Department of Anthropology and \\ Ethnology of Institute of History, Academy of Sciences of Republic of Uzbekistan, Tashkent. \\ From 2004 to 2005, he directed the Centre for Study of History of Uzbekistan at Samarkand \\ State University. His research interests are focused in the areas of Identity, ethnicity, memory, \\ Islamic shrines and sacred lineages in Central Asia, social and cultural transformation, and \\ history of Samarkand.
}

The Institute of History of The Academy of Sciences of The Republic of Uzbekistan.100060, Tashkent, Shahrisabzstreet 1, dom 5. E-mail: kungrat2002@yahoo.com

(Received 17 March 2018; Accepted 20 April 2018; Published 5 May 2018)

\begin{abstract}
In this paper the author explores the strategy of politics of memory in Samarkand, the hometown of the First President of Uzbekistan I.A. Karimov, in the post-Soviet period. The analysis concerns the traditions of Samarkand's memory culture chosen, invented or forgotten in independent Uzbekistan, to form ideas about the past using historical figures, monuments, holy places and renamed streets in Samarkand as examples. In this complex process it is important to take into consideration how the central authorities interacted with the local cultural elite of Samarkand. President Sh.Mirziyoyev formulated new trends in Uzbekistan's foreign policy, which was reflected in the politics of memory in Samarkand. These changes have become symbolic in the new politics of memory in Samarkand aimed at demonstrating the historical roots of the ethnic and religious tolerance in the society and highlighting Samarkand as a key place in the history of the Islamic world and the birthplace of the First President of Uzbekistan I. Karimov.
\end{abstract}

Keywords: Samarkand, memory, identity, shrines, streets, memorials, cultural elites, Uzbekistan, Nation-building, urban studies. 


\section{Introduction}

The past is a resource for the legitimization of power and justification of the current policy in culture and ideology. The internal goals of the politics of memory are to create some general ideas of political and cultural identity for the citizens of a country, taking into account local specificities. Politicians often apply to the events of the past, often mythical, to justify their decisions in building national statehood and in foreign policy (Verovšek. 2016). Politics of memory determines what should be remembered and what needs to be forgotten and specifies who should be recognized as a hero and who should not.

The past in people's imagination has multiple forms and consists of numerous conflicting and complex versions (Herzfeld. 1991:226). Just as there are different ways of remembering, there are different ways of forgetting (Carsten 1995: 318; Connerton, 2008). The most vivid example of exclusion and forgetting is the practice of changing toponyms, names of historical objects, streets. By replacing old names with new ones, authorities seek sources of identity and legitimacy or, in special cases, search or invent a compromise with the local society in the historical past.

The politics of memory should be understood as a communicative paradigm (Nasrallah. 2005). Intellectuals representing local authorities belonging to different ethnic and cultural layers and having a different social background play an important part. Researchers call them cultural elites who participate in the transfer of ideology from the state to the society (Adams 2004:94). Social agents of different levels, from local to central, such as historians, writers, artists and politicians, are involved in politics of memory. Intellectuals can compete with each other and offer different interpretation of historical events, figures and monuments. The selection of this or that version as 'reliable' often depends on the human factor, on the level of education of a particular intellectual, on officials and a number of other factors. Central authorities take into account the opinions of cultural elites selectively depending on the period, situation in the country and proximity of these elites to the political elite of the state. The politics of memory is closely linked with the policy of identity.

Cities are symbols of memory. While studying the city's memory and identity, it is necessary to detect the transformation of the city's symbols caused by changes in the political, ideological and religious system in certain historical periods. There are many 
symbolic functions associated with place names in modern cities. Political powers use urban landscapes to introduce and consolidate their ideological perspective in the social reality of everyday life. The renaming of streets is aimed at introducing and legitimizing a new ideological system. It is obvious that the politics of forgetting does not lead to loss of information, but results in the reorganization of the significance of certain events or historical figures (Azaryahu 1996, 318).

Samarkand, a 2750-year-old city with an eventful history, has always been one of the major cultural centers of the Middle East. Samarkand is a city with a unique fate, which has been a part of the history and cultural heritage of the entire mankind. Samarkand was famous throughout the world, and poets and historians endowed the city with different names, among which were such as 'the Garden of Saints,' 'the Paradise of the Earth,' 'the Face of the Earth,' and 'God-protected' (Malikov 2017: 10).

Rich traditions of historical description of the city, its inhabitants and culture have formed during Samarkand's long life. As Uzbekistan gained independence, political elites were given a wide range of different historical materials to choose from, which they could use to form the policy of nation building. In this article, I have attempted to explore strategies for the organization of politics of memory in independent Uzbekistan, using Samarkand, the birthplace of the First President of Uzbekistan, I. A. Karimov (1938-2016), as an example.

In view of the complexity of the problem, I will analyse the materials using historical figures, monuments, shrines and the renaming of streets in Samarkand as examples. The study is based on materials from historical sources, the author's personal interviews and observations at some public events in Samarkand during the years of Uzbekistan's independence.

I argue that to understand current processes it is important to identify the most sustainable elements of Samarkand's memory culture for the period between the Emirate of Bukhara and the present day. It is important to characterize the main features of this culture, as it helps to understand what exactly was chosen in independent Uzbekistan to form ideas about the past, using historical figures, monuments, holy places and street renaming in Samarkand as examples. It is also important to find out motives and mechanisms for the Uzbek authorities to organize the politics of memory. The main focus will be on the period of independence in Samarkand, including changes in the politics of memory starting from the presidency of Sh. M. Mirziyoyev. 


\section{Legacy of the pre-Soviet period}

In the pre-Russian period Samarkand was a part of the independent Emirate of Bukhara (1756-1868), which was governed by the Uzbek Manghyt dynasty. Before the city was included in the Russian Empire, the following few ethnic groups formed the core of Samarkand's population: Tajiks, Uzbeks, Ironi, Jews, Hindus and Afghans (Lehmann. 1852: 148,162).

In this period Samarkand had an image of an Islamic holy city and the city of Amir Temur (Tamerlane). The main sources that may help to understand the Samarkandians' perceptions of the past in the pre-Russian period are, perhaps, "Samariya" written by Abu Tahir Khoja in the first half of the $19^{\text {th }}$ century (Abu Takhir Khoji.1899) and "Qandiya". "Samariya" includes various stories about mythical and historical rulers who built Samarkand or contributed to its development. Among them are the heroes of "Shah-nameh" ("Book of Kings") by Persian poet A. Ferdowsi (940-1020): Faridun, Tur, Kay-Kavus, the ruler of Yemen Tubba, Iskander (Alexander the Great) and Timur (Tamerlane). The figure of Amir Timur and his contribution to the development of the city are highlighted in "Samariya". The work gives detailed information about Islamic shrines, saints, mosques, mausoleums and madrasahs in Samarkand (Abu Takhir Khoji.1899).

In 1868 Samarkand was included in the Russian Empire, which had its own politics of memory to promote in the region. While Samarkand was a part of the Russian Empire, two distinctive districts developed in the city: Muslim and Russian. Various confessional communities were active in the city: Muslims, Christians, the followers of Judaism and others (Morrison, 2008).

The legacy of the Russian Empire was reflected in architecture, urban topography and public rituals. The authorities formed a new politics of memory, in which the city was treated both as the administrative center of Samarkand region and as the former capital of formidable Timur (Okraina, 1890, 14 iulya, №153). So it is natural that Timur's tamgha was depicted on the official emblem of Samarkand region approved by the local Russian administration in 1890. In the Russian part of Samarkand streets, squares and parks were named after the political and cultural heroes of Russian Turkestan. 


\section{Soviet Legacy}

According to Dadabaev, "it was the Soviet authority which introduced the pattern of permitting the usage of certain historical figures and limiting the usage of others". (Dadabaev 2016:23).

In 1918-1919 there was a transition to the new policy of memory in Samarkand. Throughout the 70 years of history the Soviet policy of memory had been changing depending on different factors. The invariable directions of this policy included promotion of the ideas of communism, the Soviet internationalism, features of national culture of the "titular nations", etc.

The politics of memory in the Soviet period can be divided into several important stages. The first one falls between 1925 and 1930, when Samarkand was the capital of the Uzbek SSR. In this period a special accent was put on the Timurid heritage. KukTash, the famous slab from the Timurid throne room, was listed among objects protected by the government (TsGARUz, fond I-394, opis 3, delo 54, 1.3-28).

The policy of naming and renaming of streets reflected the ideology of the Soviet Union and its history in socialist Samarkand. By introduction of communistic symbols into urban landscapes and "politicization of toponymy", names of streets were one of forms of regime's propaganda (Niculescu-Mizil 2014: 79).

The square in the center of the Russian part of Samarkand can be the most interesting example of alterations in the policy of memory. Interestingly, the "square" has become the testing ground for "licensed" symbols taking different shapes. Construction of the square began under the Military Governor of Samarkand, A. Abramov (1868-1877), with the name of "Georgievskaya Square" (with church erected to commemorate the conquest of Samarkand). In a sense, the square was the symbol of Russian presence in this city. In 1919, monument featuring the Liberty (on the project of the Austrian architect Rusch) was erected in this place for the heroes who died in the course of the October Revolution. The area began to be called Liberty Square.

I identified the period from 1966 to 1970 , when Samarkand's 2,500 ${ }^{\text {th }}$ anniversary was organized and celebrated, as crucial factor in shaping memory debates across and in forming the urban identity of the city. In this period, for the first time in all the Soviet years, monuments to the outstanding Turkic poet A. Navoi (1441-1501), Persian-Tajik poet A. Jami and Mirzo Ulughbek (1394-1449) were erected in Samarkand. 
Academician I. Muminov (1908-1974) who initiated this project and organized these events was supported by the head of the Uzbek SSR, Sh. Rashidov (1917-1983). The Museum of the History of Samarkand and the memorial museum of Mirzo Ulughbek, the outstanding medieval astronomer, were opened in connection with the celebrations of the city's $2500^{\text {th }}$ anniversary. A two-volume edition of the history of Samarkand, where special focus was made on the period of Amir Temur, was prepared and published in those years (Istoriya Samarkanda 1969). Moscow's response to the comprehensive study of Amir Temur's personality was sharply negative, so the research into the Timurid heritage was strongly obstructed (Vakhabov, 1986).

In 1967, when the Uzbek SSR was headed by Sh. Rashidov, the memorial house of S. Aini (1878-1954), a representative of the Tajik and Uzbek literature and member of the progressist Jadid movement, was opened in Samarkand.

Urban planning in the Soviet period led to the formation of such parts as the monumental center, industrial zone and micro-rayons (Darieva and Kaschuba 2011: 17). Samarkand included these elements, but the structure was complicated by the legacy of the previous period, when the city was divided into the old and a new cities. In the Late Soviet period the ideological centre of Samarkand was the Lenin square with his monument, where public events were organized several times a year. The main streets in Samarkand were named after K. Marx, V. Lenin, F. Engels, 'red commander' M. Frunze, Uzbek Communists F. Khodzhayev, A. Ikramov and U. Yusupov, Soviet cosmonauts Yu. Gagarin and G. Titov and others.

\section{Nation building in Uzbekistan and the cultural elites of Samarkand}

Researchers that studied the nation building in Uzbekistan analyzed primarily the general policy and festivals in Tashkent (Adams 2010). Some researchers simplify the strategy of the nation building policy in Uzbekistan, which, in their opinion, has 'a high level of the nationalistic primordial idea' (Kudaibergenova 2014, 160). In fact, the organization of the identity and memory politics in Uzbekistan is much more complex and contextual. I argue to better understand this policy it is necessary to take into account the role of local cultural elites, which carry on a kind of dialogue with the central authorities. 
The idea of internationalism, which is was widely propagandized during the Soviet era, had a certain influence on I. Karimov and his environment (Adams 2010: 194). Following the ideas of internationalism and pursuing tolerant ethnic and religious policy, the authorities established the Museum of the Bukharan Jews in Samarkand in 2008.

Researchers proposed the concept of 'post-socialist urbanism' to describe changes local authorities made within the space of the city, and the impact of global trends and people's reaction to these changes (Darieva and Kaschuba 2011: 12-13). So there is a question: What was the authorities' attitude to the symbols of socialism in public places? There are various ways of post-socialist transformation and experiences.

The implementation of the politics of memory in Samarkand during the years of Uzbekistan's independence can be divided into several stages: the 1990s, after 2007 and after September 2016.

When the country was headed by I. Karimov (1991-2016), the politics of memory had the following tasks: to legitimize the new state, propagandize the achievements of the independence period and the contribution of I. Karimov to the development of Uzbekistan, and promote Uzbekistan's international relations. The Russian Empire and the Soviet period were interpreted in a negative way, while the period of independent Uzbekistan was praised. The search for balance between the multiethnic and multiconfessional nature of the population and promotion of development of the Uzbek nation started.

Samarkand has always been a multiethnic city. It was inhabited by such nationalities as the Ironi, Jews, Russians, Tajiks, Uzbeks, Kazan and Crimean Tatars, Armenians, Koreans and others. Since the 1990s large numbers of the Bukharan Jews have for various reasons migrated from Uzbekistan, and most of them have left Samarkand. The outflow of the Russian-speaking population was also considerable. Currently, the main ethnic groups forming the core of Samarkand's population are Tajiks, Uzbeks, Ironi, Tatars, Russians. Samarkand is a multi-confessional city. It has Sunni and Shiite mosques, Orthodox churches, a Catholic church, an Armenian church and a synagogue. 
Several levels of 'imaginary societies,' such as the Samarkandians, Tajiks, Ironi, Uzbeks, Uzbekistanians, Muslims and others, can be identified in Samarkand. People have multiple identities, one of which is shown in different contexts and situations.

In order to understand the politics of memory in Samarkand, it should be taken into account that the First President of Uzbekistan I. Karimov was born in Samarkand and had connections with the city and regional administration and with some of the local intellectuals, e.g. the Institute of Archeology, who expressed their vision of the city's history. Developing the politics of memory in Samarkand the authorities took into account the opinion of certain intellectual circles in the heterogeneous population of Samarkand. Organizing the politics of memory the central Uzbek authorities avoided heroizing those individuals whose conflicting activities could split the society in Samarkand. I. Karimov put a special stress on the multiethnic nature of the Uzbek nation. In his book "Uzbekistan on the Threshold of the $21^{\text {st }}$ century" he emphasized: “...we also have common cultural, historical and anthropological roots with the Tajik people, and this fact gives us the full right to consider our culture as a unique synthesis of Turkic and Persian cultures" (Karimov 1997:122-123). Beginning from the 2000 in state ideology of Uzbekistan has been increased the intension to create new idea, which would be able to consolidate the society in Uzbekistan, including not only Uzbeks, but other nationalities of the country (Karimov 2001).

"Samariya" has been several times re-issued in the years of Uzbekistan's independence together with another medieval work on the history of the city, "Qandiya" (Abul Khakimi Samarqandi, 1994).These works became reference books for a number of local historians in Samarkand.

The politics of memory in Samarkand was also largely based on particular opinions of local cultural elites. Certain historians from the Samarkand State University took an active part in committees for the toponymy of Samarkand. M. Abramov (1926-1998), who was awarded the state order "Dustlik", made a significant contribution to the study of the toponymy of Samarkand and the renaming of streets in the first half of the 1990s. (Abramov 1989).

Professor T. Shirinov who at the time headed the Institute of Archaeology and later was the rector of the Samarkand State University played a prominent role in the organization of Samarkand's $2750^{\text {th }}$ anniversary event. A new trend was detected in the 
course of the preparation for the celebration, which contrasted with those prevalent in the Soviet period and consisted in focusing on the history and appearance of holy places, with a special stress on shrines popular in the Islamic world and those demonstrating the tolerance and multiconfessionality of Samarkand. Samarkand's role in the history of the world civilization was studied to highlight the period of independence and propagate achievements made at this time.

Academician B. Valikhojaev (1932-2005) and historian K. Kattaev, who was the descendant of Mahdumi Azam, an outstanding $16^{\text {th }}$ century Sufi leader, made a significant contribution to the study of the city's history. They published a number of research works on the life of major religious figures from Samarkand and on the city's historical monuments (Kattaev 1994; Valikhojaev, 1994). The Samarkand municipal and regional authorities use their works for implementing cultural policy. Among the representatives of cultural elite of Samarkand in the era of independence it is possible to call the names of Kh.Davron, I. Suvankulov, V. Ionesov, R. Nazaryan, T. Rakhmatullaev etc.

Among the Samarkand intellectuals there are many activists supporting the study and popularization of the city's history. Thanks to the writer N. Rahmat, the first monument to Jadid leader M. Behbudi (1874-1919) was erected in Samarkand in 2006. It took him almost one year to convince some officials of the necessity to build the monument (Rakhmatullaev, 2017).

\section{Historical figures and monuments of Samarkand}

In Soviet and post-Soviet years, Samarkand underwent a crucial process of transformation, which affected urban toponyms, monuments and major public buildings.

Independence period became the culmination in the positive estimation of Temur's role in the history of Central Asia. The grand celebration of the $660^{\text {th }}$ jubilee of Amir Temur in 1996 became a major event in the development of the policy of memory in Samarkand. In 1996 two minarets of the Gur-Emir mausoleum, where Timur and his descendants are buried, have been restored. On October 18, 1996 I.A. Karimov has awarded Temur's (Amir Temur's) order to Samarkand and has suggested establishing that day as an official City Day. From now on this holiday is traditionally celebrated in Samarkand (Khusanov 2018a). 
The strengthening of Temur's image as a great ruler is promoted both by the official policy in Uzbekistan and also by numerous monumental buildings (mosques and mausoleums), constructed by his order in Samarkand.

The history of Samarkand and its various interpretations are reflected in local newspapers, such as "Zarafshan", "Samarkandskiy Vestnik", "Samarkand" and others, with "Samarkand" issued in two languages, Uzbek and Tajik. The newspaper "Ovozi Samarkand" issued by Samarkand's hokimiyat (municipality) is printed only in Tajik and has a website where information about the history and culture of Samarkand is given (Ovozi Samarkand).

As Uzbekistan gained independence, there arose the question of Samarkand's emblem, which was designed by Russian artist and sculptor G. I. Ulko and approved by the government in 1994 (Khusanov 2018b). After some discussion, the authorities of Samarkand decided to refuse from the symbols of Amir Temur's and the Temurids' time and opted for the image of a snow leopard. Thus, a pre-Islamic sign - the winged snow leopard whose story was taken from the late medieval sources, was preferred as the city's identifier to symbols of the Islamic era.

After the independence of Uzbekistan the authorities started to selectively remove monuments of Samarkand of the Soviet era. Considerably quickly, in 1991 monuments of V. Lenin had been dismantled. Gradually, year by year they began to remove other monuments among which were: monument to the Soviet writer M. Gorky, Uzbek Soviet political and military leaders, figures Yu. Akhunbabayev, A. Ikramov, M. Mirsharapov. The authorities had also renamed the streets called in their honor.

After 2007 the policy of memory in Samarkand has gained more centralized character that was shown in the radical solution of the issues connected with historical memorials, for example, in 2009 monument of Liberty was destroyed and the monument to the founder of classical Tajik poetry of a Samanid era Abu Abdullo Rudaki has been built on its place.

Since 1992 V. Lenin's Square has lost its functions of the public downtown where there demonstrations took place. The monument of Timur was built in absolutely another place, which is near the Gur-Emir mausoleum, where he was buried. 


\section{Renaming the streets of Samarkand}

Street names in Samarkand from the nineteenth century to the present include national, local, and international or transnational names, with different choices for each of the periods.

After the independence of Uzbekistan the policy on renaming of city streets was pursued. As researchers note, in the countries of Central Asia, streets and cities had been renamed, names of Communistic public figures disappeared and were replaced with all types of heroes of the pre-Soviet past (Abashin. 2012, 151-152).

Names of streets in honor of persons or events had been supported in memory of Samarkand people through celebrations, for example, after the independence of Uzbekistan people began to celebrate the birthday of Temur, A. Navoi, etc.

Researchers argue that people are inclined to connect the name of the street with local events which actually happened on this street or in important people of this street. (Alderman, Rose - Redwood and Azaryahu 2008). One of the strategies of renaming of streets consisted in replacement of names of streets in honor of local figures, activists, historic figures of local level, who are not well-known outside Samarkand. Officials from mahalla committees were involved in the renaming process, which resulted in some streets within a mahalla named in honour of this or that outstanding representative of the quarter. This type of practice had been particularly widespread across the noncentral districts of Samarkand.

The analysis of names of the largest streets shows that they include: names of classics of the Persian-Tajik, Karakalpak, Russian, Turkic, Tatar, Turkmen, Uzbek, Georgian literatures: A. Rudaki, Umar Khayyam, A.Firdousi, A. Djami, H. Dekhlavi, Pakhlavon Mahmoud, A. Navoi, Lutfi, Babur, Zebuniso, M. Kashgari, Makhtumkuli, Yusuf Balasaghuni, Berdakh, Anbar-otin, Uvaysi, Makhtumkuli, Nodirabegim, A.S. Pushkin, L. Tolstoy, A.P. Chekhov, G. Tukaev etc.

The following historic figures have found reflection in names of streets of Samarkand: Real and mythical heroes of ancient Sogd and Central Asia - Spitamen, Shirak, Tomiris. Famous Central Asian medieval intellectuals: Ibn Sino, Abu Raykhan Beruni, Muhammad Musa al-Khorezmi, Ahmad al-Ferghani, Abu Nasr al-Farabi, Imam of al-Bukhari, Abu Mansour al-Moturidi, B. Marghilani. 
Islamic saints (Sufi leaders) are also prominent personalities among the ones celebrated in the collective memory by naming a street (Yusuf Hamadoni, Ahmad Yassavi, Abduhalik Gijduvani, Khoja Ahror-I Vali, Bahauddin Naqshband, Nur al-Din Basir, Mahdumi Azam, Sufi Allayar).

Rulers, poets and scholars of Timurid's era: Amir Temur, Shahrukh, Mirzo Ulughbek, Hussayn Boyqaro, Babur, Ali Qushchi, Giyasaddin Jamshed Qashi, Qazyzade, Ibn Haldun. One of Samarkand's streets was named after Ruy González de Clavijo, the Castilian ambassador to Amir Timur's court. When Uzbekistan was establishing close links with Spain during the Independence era, the authorities imparted a symbolic meaning to his name.

In Samarkand during the Soviet period there were two big streets called in honor of the first and second cosmonauts: Yu. Gagarin and G. Titov. In 1990s G. Titov street has been renamed in honor of the classic of the Persian-Tajik poetry Abu Abdullo Rudaki.

Local scholars, cultural and political figures of Samarkand Uzbek, Tajik, Persian, Jewish, origins: U. Dzhurakulov, academician V. Abdullaev, O. Makhmudov, A. Lahuti, T. Zehni, M. Leviev, G. Tukayev, G. Mulokandov.

The numerous categories are made by names of streets with the geographical name. A small number of streets carry names of traditional quarters (guzars) of Samarkand: Kavarzor, Lolazor, Chorrakha, Qushkhauz, Namazgoh, Suzangaron, etc.

Researchers note that the political elite of Uzbekistan pay little attention to representatives of semi-nomadic Uzbeks, such as Sheybani Khan (Adams 2010). In Samarkand many streets bear the names of numerous Timurids; however, there is one named after Sheybani Khan (since the 1990s), a representative of the Ashtarkhanid elite, Yalangtushbiy Bahadur (1578-1656), one of those who created Registan, and Emir of Bukhara Shahmurad (1785-1800). The renaming was based on several principles. These were some selected territorial and cultural criteria.

In 2016 Tashkent street was renamed Islam Karimov street. On September 2, 2017 a monument to Islam Karimov was erected near the Registan Square.

Currently, the ideas of Samarkand's people about the city's past diverge. Most of the younger people that were born after 1991 do not remember Soviet-time memorials and street names. In their minds, one of the most remarkable pages in the history of the city is directly associated with the era of Timur and Ulughbek. 


\section{Shrines and memorial complexes in Samarkand}

Researchers admit that in the independence years the government of Uzbekistan 'has instrumentalised Islam as part of its nation-building strategies.' (Rasanayagam 2011. 96).Researchers note that the Uzbek government distinguishes between "good" and "bad" Islam and considers that the "good Islam" is the one that is non-political, culturally authentic and tolerant of other religions (Rasanayagam 2011: 96). I agree with this statement, as the Tomb of Saint Daniel (Khoja Doniyor) in Samarkand - the wellorganized shrine of three religions, Islam, Christianity and Judaism - illustrates that the government supports this very manifestation of religion in the region.

Shrines of Samarkand can be divided into several categories. Some are completely under the control of the government (Shah-i-Zinda, Daniyar, Chokardiza), while others were rebuilt in the 1990 s by private initiators (the shrine of the Sufi saint Nur al-Din Basir).

Chokardiza was one of the famous cemeteries and Islamic holy places in Samarkand in the pre-Soviet period. In the Soviet period, the cemetery and graves of Islamic theologians were destroyed. In 1999-2000 the First President of Uzbekistan I. Karimov decreed that a part of the cemetery together with the grave of the famous theologian Abu Mansur al-Mothuridi (870-944) was restored. A memorial complex was built on the site (Malikov 2005: 641). In 2000, the 1,130 ${ }^{\text {th }}$ anniversary of the scientist's birth date was widely celebrated in Uzbekistan. Works on the improvement of the territory continue even now. The research group headed by K. Kattaev identified the place in the cemetery where Imam Burhan al-Din al-Marghinani, an author of famous book on Islamic jurisprudence "Al-Hidaya”, was buried (Rustamov, 2018).

Timur (Tamerlane) is known to have revered holy Sufi Nur al-Din Basir (died in 1249) and initiated the construction of a mausoleum on his grave (Abu Takhir Khoji. 1899: 181). The Samarkand colonial authorities decided to demolish the mausoleum in 1880. The saint's remains were re-buried at the Hazrat-Khizr cemetery. Muazzaskhan, a descendant of the Sufi leader Mahdumi Azam, built a mausoleum over Nur al-Din Basir's grave at her own expense in 1997. Currently, this place is regarded as holy (Suvonqulov 2007:51-52). 
The memorial complex of I. Karimov created in 2017-2018 has become a new memorial in the post-Karimov period in the history of Samarkand.According to his will, First President of Uzbekistan Islam Karimov was buried in the complex of Hazrati Khizr mosque in Samarkand, on September 3, 2016 (Memorial 2018). A memorial complex is being built in the city of Samarkand in accordance with the resolution of the President of Uzbekistan Sh.Mirziyoyev "On perpetuating the memory of the First President of the Republic of Uzbekistan Islam Abduganiyevich Karimov" of January 25, 2017. The motive for choosing the site for I. Karimov's grave was not officially explained. Probably, the authorities followed the medieval Central Asian tradition of burying a ruler next to the grave of a saint. According to "Samariya", the Hazrat Khizr mosque is considered to be the holy place where the first mosque of Samarkand was built (Abu Takhir Khoji. 1899); besides, next to it there are the graves of the Sayyids. Not far from this place, in the neighboring holy cemetery of Shah-i-Zinda, is the grave of I. Karimov's mother. It is important that the shrine of Timur's pir (spiritual guide) Nur al-Din Basir is situated near I. Karimov's grave, to the north of it.

Masters from India and various regions of Uzbekistan were engaged in the construction of the mausoleum. Activity on erecting the memorial complex was carried out jointly with UNESCO. Ayats from the Quran are written on the walls in Uzbek, Arabic and English (Elmurodov and Khasanov 2018).

The election of Sh. Mirziyoyev President of Uzbekistan in 2016 marked a new page in the history of the country. Noticeable changes have been made in Uzbekistan's foreign strategy aimed at building more open and broader relationships with other countries, especially in Central Asia.

The changes that have taken place are reflected in the politics of memory in Tashkent, the capital of Uzbekistan, and in Samarkand. The improvement of relations with China will be resulted in the opening of a monument to Confucius in the city.

In March 2018 the old removed monument to A. Jami and A. Navoi has been reerected in the centre of Samarkand. This event coincided with sharp improvement of relations between Uzbekistan and Tajikistan, the first official visit of President of Uzbekistan Sh. M. Mirziyoyev to Tajikistan and abolition of the Uzbek and Tajik visas for the citizens of the two respective countries. 
Currently, there is a big plan to expand the complex of Muhammad ibn Ismail alBukhari (810-870), the great expert in the Hadith, and create an international academic and educational centre. The authorities believe that this will help understand Islam, train high-quality specialists and enhance the reputation of Uzbekistan in the Islamic world.

Thus, the politics of memory in Samarkand is aimed at the symbolic reformation of reality, consolidation of a certain image of the past in the minds of citizens and construction of new meanings and senses.

\section{Conclusion}

The present research only offers preliminary conclusions, which can stand as premises for future research. In I. Karimov's era the politics of memory in Samarkand had the task of legitimizing the new state, specifying ancient sources of culture, establishing the contribution of the Samarkand people to the world civilization and propagandizing the achievements of the Independence.

I argue that the idea of internationalism widely propagated in the Soviet era had an impact on I. Karimov and political elites, which to a certain extent followed this tradition. In the Independence period the names of the streets connected with the communist past have gradually been changed, and most of the monuments to Soviet leaders and events of the Soviet era have been removed.

Contrary to the Soviet era, in the period of the independence a new trend formed in Uzbekistan to focus on the history and improvement of holy places, with an accent on shrines popular in the Islamic world and those demonstrating the tolerance and multiconfessionality of Samarkand.

Based on my research I argue that representatives of the local cultural elite were in contact with the central government and influenced these or those aspects of the politics of memory in Samarkand. These ties were seen in the 1990s, when, forming the politics of memory in Samarkand, the authorities took into certain account the interests of the local elite, which was not uniform and consisted of representatives of different ethnic groups, such as Tajiks, Ironi, Jews, Uzbeks, Russians and some others. To this day representatives of the cultural elite of Samarkand diverge in their interpretation of the cultural history of the region. 
The politics of memory in Samarkand is aimed at the formation of cultural identity based not on the division of representatives of cultures into 'insiders' and 'outsiders,' but on the creation of proper ideological conditions for the peaceful coexistence of various ethnic groups in the city. Therefore, people of different ethnic origins, including Persians, Tajiks, Turkmen, Uzbeks, Jews, and others, were present among historical figures immortalized in the names of the streets, monuments and squares of Samarkand. The Soviet heritage, local peculiarities and specific character of the policy pursued by the Uzbek authorities influenced the selection of these persons.

The election of Sh. Mirziyoyev as President of Uzbekistan in 2016 was the beginning of the development of a new strategy in Uzbekistan's foreign policy aimed at building more open and broader relationships with other countries, especially in Central Asia. These changes have become symbolic in the new politics of memory in Samarkand aimed at demonstrating the historical roots of the ethnic and religious tolerance in the society and highlighting Samarkand as a key place in the history of the Islamic world and the hometown of the First President of Uzbekistan I. Karimov.

Conflicts of Interest: The author declares no conflict of interest.

\section{References}

Abashin, Sergey. (2012). Nation-construction in post-Soviet Central Asia. M. Bassin \& C. Kelly (Eds.), Soviet and Post-Soviet Identities. Cambridge: Cambridge University Press.

Abramov, M.M. (1989). Guzari Samarkanda. Tashkent: Uzbekistan.

Abul Khakimi Samarqandi. (1994). Qandiya. Tarjimon, s' oz boshi, izoh va lug'at muallifi K. Kattaev. Samarqand: Sug'diyon.

Adams, Laura. (2010). The Spectacular State: Culture and National Identity in Uzbekistan. Durham: Duke University Press.

Adams, Laura L. (2004). "Cultural Elites in Uzbekistan: Ideology Production and the State." The Transformation of Central Asia: States and Societies from Soviet Rule to Independence. Edited by Pauline Jones-Luong. Ithaca, NY: Cornell University Press: 93-119. 
Alderman, Derek, Rose - Redwood, Reuben, Azaryahu, Maoz. (2008). Collective Memory and the Politics of Urban Space: an Introduction. Geo Journal 73: 161-164

Azaryahu, Maoz. (1996). The Power of Commemorative Street Names. Environment and Planning D: Society and Space 14: 311-330. https://doi.org/10.1068/d140311

Carsten, Janet. (1995). The Politics of Forgetting: Migration, Kinship and Memory on thePeriphery of the Southeast Asian State. Journal of the Royal Anthropological Institute. Volume 1. No. 2: 317-335.

Connerton, P. (2008). Seven types of forgetting.Memory Studies, 1(1): 59-71

Darieva, Tsypylma and Kaschuba Wolfgang. (2011). Sights and Signs of Postsocialist Urbanism in Eurasia: An Introduction in Urban Spaces after Socialism Ethnographies of Public Places in Eurasian Cities. University of Chicago press.

Dadabaev, Timur. (2016). Identity and Memory in Post-Soviet Central Asia: Uzbekistan's Soviet Past. Routledge.

Elmurodov, Matnazar and Khasanov, Golib. (2018). Memorial complex of Islam Karimov has been opened in Samarkand. Accessed, 20 ${ }^{\text {th }}$ April 2018, from: http://uza.uz/en/politics/memorial-complex-of-islam-karimov-has-been-opened-insamarka-30-01-2018

Herzfeld, Michael. (1991). A Place in History. Social and Monumental Time in a Cretan Town. New Jersey: Princeton University Press.

Istoriya Samarkanda. (1969). Tom 1. Otvetstvenniy redactor I.M.Muminov. Tashkent: Fan.

Karimov, I.A. (1997). Uzbekistan on the threshold of the Twenty-first century. Tashkent: Uzbekiston.

Karimov, I.A. (2001). Za protsvetaniye Rodini - kajdiy iz nas v otvete. Volume 9. Tashkent: Uzbekiston.

Kattaev, Komilkhon. (1994). Makhdumi Azam va Dakhbed. Samarqand: Sugdiyon.

Khusanov, Rustam. (2018a). Istoriya Samarkanda. Accessed, $20^{\text {th }}$ April 2018, from: http://e-samarkand.narod.ru/history.htm Avtorskiy project R.Khusanova

Khusanov, Rustam. (2018b). Geraldika Samarkanda. Accessed, 20 April 2018, from: http://e-samarkand.narod.ru/gerb.htm 
Kudaibergenova, Diana T. (2014). National identity formation in post-Soviet Central Asia: The Soviet legacy, primordialism, and patterns of ideological development since 1991. Social and Cultural Change in Central Asia. The Soviet legacy. Edited by Sevket Akyildiz and Richard Carlson. Routledge.

Lehmann. (1852). Alexander Lehmann's Reise nach Buchara und Samarkand in den jahren 1841 und 1842, St. Petersburg.

Malikov, A.M. (2017). Istoriya Samarkanda (s drevnikh vremen do seredini XIV veka). Tom 1. Tashkent: Paradigma.

Malikov, Azim.(2005). Chokardiza. O’zbekiston milliy entsiklopediyasi 9 jild. Toshkent.

Maurantonio, Nicole. (2014). The Politics of Memory. The Oxford Handbook of Political Communication. Edited by Kate Kenski and Kathleen Hall Jamieson. Oxford: Oxford University Press.

Memorial. (2018). Memorial complex of Islam Karimov has been opened in Samarkand. Accessed, 20 ${ }^{\text {th }}$ April 2018, from: http://www.pressservice.uz/en/lists/view/1464

Morrison, A.S. (2008). Russian rule in Samarkand. 1868-1910. A comparison with British India. Oxford university press, 2008

Nasrallah, Laura. (2005). The Politics of Memory. Harvard Divinity Bulletin Autumn. Vol. 33, No. 2.Accessed, 20 April 2018, from: https://bulletin.hds.harvard.edu/articles/autumn2005/politics-memory

Niculescu-Mizil, Ana-Maria. (2014). Re-Naming Streets in Contemporary Bucharest: From Power Distribution to Subjective Biography. Analize - Journal of Gender and Feminist Studies. New Series. Issue No. 3: 69-94

Okraina, 1890.14 iulya. №153

Ovozi Samarkand. Accessed, 20 April 2018, from: http://ovozisamarqand.uz/index.html

Rakhmatullaev, Toshpulot. (2017). Makhmudkhoja Bekhbudi: prava ne dayutsa, a zavoevivayutsa. Accessed, 20 April 2018, from: http://rtoshpulat.blogspot.jp/2017/01/blog-post_20.html

Rasanayagam, Jonan. (2011). Islam in Post-Soviet Uzbekistan. The morality of experience. Cambridge university press.

Rustamov, Yormamat. (2018). Naydeno mesto zakhoroneniya imama Burkhoniddina Marginoni. Accessed, 20 April 2018, from: https://sv.zarnews.uz/news/1121 
Abu TakhirKhoji. (1899). «Samariya». Opisanie drevnostej i musulmanskikh svyatin Samarkanda. Perevod V. Viatkina in Spravochnaya knijka Samarkandskoi oblasti. 1898. Vipusk VI. Samarkand.

Suvonqulov, Inoyatulla. (2007). Svyatini Samarkanda. Tashkent: Fan, 2007

TsGARUz - Tsentralniy gosudarstvenniy arkhiv Respubliki Uzbekistan, fond I-394, opis 3, delo 54 , 1.3-28

Vakhabov, M.G. (1986). Pravde istorii vopreki. Pravda Vostoka. December.

Valikhojaev, Boturkhon. (1994). Khoja Akhror tarikhi. Toshkent: Yozuvchi.

Verovšek, Peter J. (2016). Collective memory, politics, and the influence of the past: the politics of memory as a research paradigm. Politics, Groups, and Identities, 4:3, 529-543, DOI: 10.1080/21565503.2016.1167094

To cite this article:

Azim Malikov 2018. The politics of memory in Samarkand in post-Soviet period

International Journal of Modern Anthropology. 2 (11): 127 - 145

DOI: http://dx.doi.org/10.4314/ijma.v2i11.6

\section{(9) $\mathbb{P} \otimes \Theta$}

This article, as all articles published in this journal, is under The Creative Commons Attribution:

Attribution-NonCommercial-NoDerivatives 4.0 International (CC BY-NC-ND 4.0).

https://creativecommons.org/licenses/by-nc-nd/4.0/ 